\title{
Granular cell myoblastoma of the eyelid margin
}

\author{
*Z. FRIEDMAN, **E. EDEN, AND *E. NEUMANN
}

From the *Eye Department, and the **Pathological Department, Rothschild Hospital, Haifa, Israel

Granular cell myoblastoma (granular cell schwannoma) is a rare tumour of uncertain origin, which is thought to derive either from muscle cells or from Schwann cells. The tumour has been found in various organs, but only very infrequently in the eye and ocular adnexa. This paper reports, for the first time, a case of primary involvement of the lid margin and tarsus by granular cell myoblastoma.

\section{Case report}

A 45-year-old man was admitted to the eye department in February, 1968, for excision of a tumour of the left upper lid where it had appeared 6 months earlier.

\section{Examination}

The tumour consisted of a hard, sessile mass $4 \times 2 \mathrm{~mm}$. in size, situated at the junction of the middle and the lateral thirds of the lid margin, apparently fixed both to the skin and to the tarsus. The rest of the ocular examination was normal and the general physical examination was negative.

Surgery

The tumour was removed by simple excision on August, 7 ig68.

\section{Histology}

The specimen was fixed in formalin and mounted in paraffin, and sections were stained with haemotoxylin and eosin, periodic acid-Schiff, van Gieson, and for reticulin fibres.

Microscopic examination (Figs I and 2, overleaf) revealed irregularly arranged bundles, sheets, and nests of densely packed large polyhedral faintly eosinophilic cells. The cytoplasm contained eosinophilic granules which stained with P.A.S. The nuclei were small, hyperchromatic, and of uniform size. A very slender reticulin and fibrous framework was discernible within the tumour.

\section{Course}

One month after the operation there was a recurrence at the same site. The tumour grew slowly and 6 months later consisted of a hard fixed mass on the lid margin, $4 \times 6 \mathrm{~mm}$. in size, over which the cilia were missing (Fig. 3, overleaf). On July 13, 197 I, a wedge resection was performed, including $2 \mathrm{~mm}$. of normal lid on each side of the tumour. Microscopic examination again revealed a granular cell myoblastoma, completely excised, with histological features identical to those described above. At the time of writing there is no sign of a recurrence. 


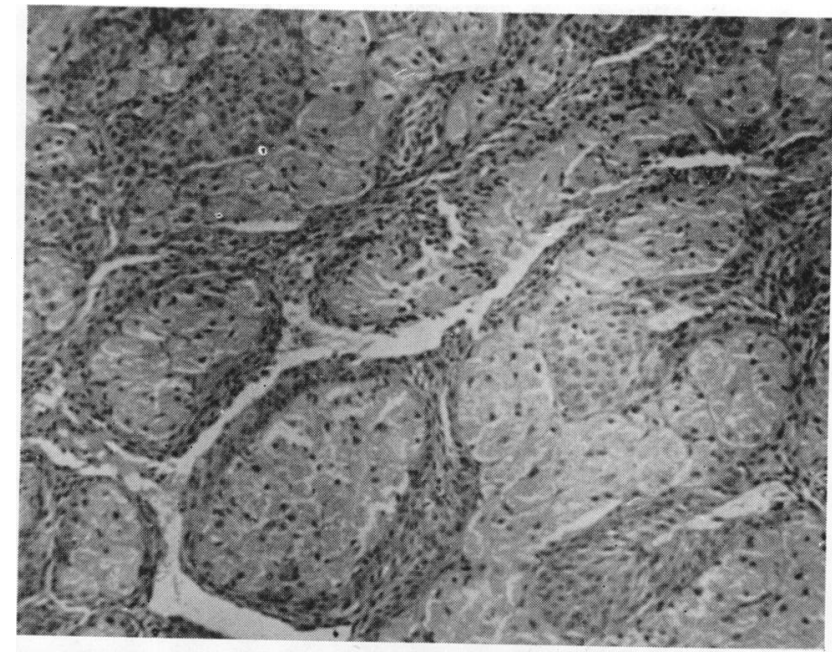

FIG. I Granular cell myoblastoma. Groups of large polyhedral cells with small hyperchromatic nuclei and eosinophilic granules in cytoplasm. Note reactive epithelial hyperplasia of the skin of the upper eyelid. Haematoxylin and eosin. $\quad \times 120$

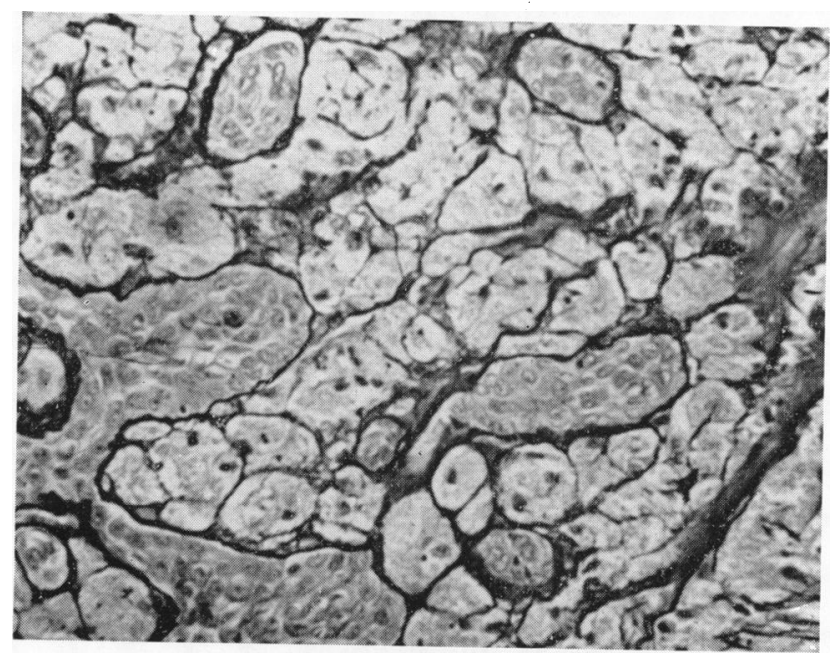
FIG. 2 Granular cell shows the sparse reticulin and 흠이 collagen fibre network within the tumour. Reticulin stain. $\times 225$

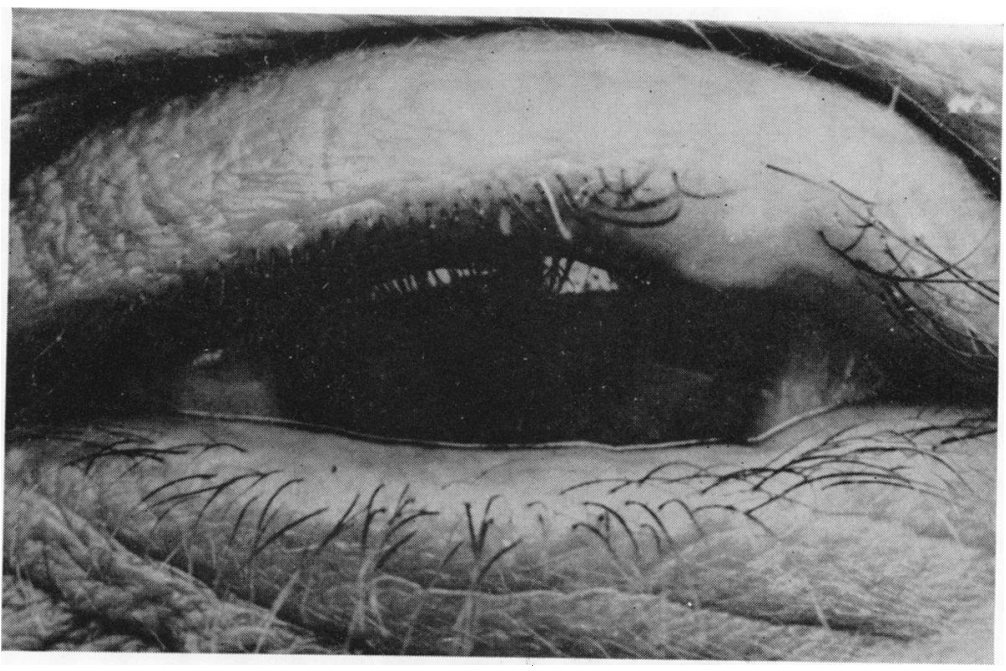

FIG. 3 Recurrent granular cell myoblastoma of upper lid margin. Note absence of lashes over the tumour. 


\section{Discussion}

Abrikossof (1926) suggested the name granular cell myoblastoma for a group of tumours with a widespread distribution throughout the body that appear in the form of hard nodules fixed to the surrounding tissues. The tumour has been found mostly in the tongue (one-third of cases), in the skin and subcutaneous tissue (one-fifth of cases), in skeletal muscle, in the gastrointestinal, respiratory, and genitourinary tracts, and in the pituitary gland (Pearse, I950; Azzopardi, 1956; Burston, John, and Spencer, 1962). It usually appears at the age of 30 to 50 years, without predilection for either sex. Most are benign, but malignant cases have been reported (Dunnington, I948; Ross, Miller, and Foote, 1952; Gamboa, 1955). Histologically these tumours consist of cells containing eosinophilic granules, which stain P.A.S.-positive, and small central nuclei. Scarce reticulin and collagen fibres surround groups of tumour cells.

The tumour was first thought to originate from skeletal muscle cells as a degenerative, regenerative, or neoplastic process (Klemperer, 1934; Gray and Gruenfeld, 1937; Crane and Tremblay, 1945; Willis, 1953). This theory stressed the frequent finding of transitional forms of cells, but it did not explain the finding of the tumour in organs devoid of skeletal muscle, such as the pituitary gland and viscera; moreover, the tumour cells lack crossed and longitudinal striation and they do not contain glycogen (Azzopardi, I956).

Recent histochemical and electron microscopic studies suggest that the tumour may arise from Schwann cells, thus explaining its widespread distribution. Histochemical staining shows that the cytoplasmic granules contain phosphatids and cerebrosides which resemble disintegration products of myelin (Azzopardi, I956; Fisher, and Wechsler, 1962). Electron microscopy has revealed material which resembles degenerative forms of myelinated axons inside the tumour cells. Normal Schwann cells may also be seen inside the tumour (Fisher, and Wechsler, I962).

The occurrence of granular cell myoblastoma in the eye and ocular adnexa is rare and apparently the diagnosis can only be made histologically. Involvement of the eyelid by granular cell myoblastoma has been reported by several authors, but apparently none was localized on the lid margin, and tarsal involvement has not been reported. Powell (1946) reported a case of a woman with granular cell myoblastoma involving the ovaries, the retroperitoneal space, and the subcutaneous tissue in several places, including the upper lid. Cristini ( 1946 ) reported one case and referred to the histological features of five previously reported cases of granular cell myoblastoma of the eyelid. We could find no clinical description of these tumours which mentioned their exact localization. Timm and Timmel ( 1966 ) reported two cases of granular cell myoblastoma; one was on the upper lid just below the eyebrow, the other in the lower lid probably well away from the lid margin.

Two cases of granular cell myoblastoma in the region of the lacrimal sac simulating acute dacryocystitis have been described; one was benign (Bahr, 1938), the other malignant (Dunnington, 1948).

Isolated cases of granular cell myoblastoma have been described attached to the extraocular muscles, causing proptosis and diplopia (Dunnington, 1948; Morgan and Fryer, 1969). Single cases have also been found in the eyebrow (Blodi, I956; Dhermy, Morax, and Jolivet, 1966). A unique case was reported in which the tumour developed inside the eye from the ciliary body and protruded into the anterior chamber (Cunha and Lobo, 1966). 


\section{Summary}

A slowly-growing benign form of granular cell myoblastoma, involving the upper eyelid margin and infiltrating the tarsus, is reported. The tumour was fused with the surrounding tissues and could be totally excised only by wedge resection.

The literature on this type of tumour is reviewed with particular reference to ocular involvement.

\section{References}

ABrikossoff, A. (1926) Virchows Arch. path. Anat., 260, 2 I 5

azzopardi, J. G. (1956) F. Path. Bact., 71, 85

BAHR, G. vON (1938) Acta ophthal. (Kbh.), 16, I09

BLOdI, F. C. (1956) Arch. Ophthal. (Chicago), 56, 698

Burston, J., John, R., and SPEncer, H. (ig62) 7. Path. Bact., 83, 455

Grane, A. R., and tremblay, R. G. (1945) Amer. J. Path., 21, 357

CRISTINI, G. (1946) Rass. ital. Ottal., 15, 207

cunha, s. L., and lobo, F. G. (Ig66) Brit. J. Ophthal., 50, 99

Dhermy, p., morax. P. v., and Jolivet, J. (I966) Ann. Oculist. (Paris), 199, 1025

Dunnington, J. H. (1948) Arch. Ophthal. (Chicago), 40, I 4

Fisher, E. R., and Wechsler, H. (1962) Cancer (Philad.), I5, 936

gamboa, L. G. (1955) A. M. A. Arch. Path., 6o, 663

gray, s. h., and GRUenfeld, G. E. (1937) Amer. J. Cancer, 30, 699

KLEMPERER, P. (I934) Ibid., 20, 324

MORGAN, L. R., and FRYER, M. P. (1969) Plast. reconstr. Surg., 43, 315

pearse, A.G.e. (1950) J. Path. Bact., 62, $35^{\mathrm{I}}$

POWEll, E. B. (1946) Arch. Path., 42, 517

Ross, R. C., Miller, T. R., and foote, F. W. (1952) Cancer (Philad.), 5, I I 2

timm, G., and timmel, H. (1966) Klin. Mbl. Augenheilk., 148, 665

Willis, R. A. (1953) "Pathology of Tumours", 2nd ed., p. 743. Butterworth, London 